\title{
BEYOND SELF
}

\author{
Thomas HORA
}

New York, N.Y.

Motto:

When the ancient Chinese scholar Yen Hui was considering becoming court advisor to the ill-famed ruler of his time, he came to his teacher Chuang-tzu for advice. Chuang-tzu warned him that he is in great danger of being beheaded unless he learns "mind-fasting." Heedful of the advice given him, Yen Hui retired to practice "mind-fasting" in accordance with his teacher's instructions.

Three years later, Yen Hui returned to his teacher saying that he thinks he is ready for his assignment. The master challenged him to prove it. Whereupon Yen Hui said: "Before I disciplined myself in mind-fasting as you instructed me, I was fully conscious of being Yen Hui. Now that I have perfected myself in the discipline, I realize that from the beginning there never was a Yen Hui.",

The master said: "Yes, you realized "hsu," which translated means "Emptiness." (1)

Voodoo is a primitive tribal method by which illness, suffering, and on occasions even death is inflicted upon a condemned individual. This is accomplished by sticking pins into an effigy doll. The amazing effects of this method demonstrate the vulnerability of man in whose consciousness the body as the "I am" represents primary reality. In the consciousness of the victim the voodoo doll becomes an extension and a representative of the self and whatever happens to this image is experienced by the victim personally and directly. In other words, the abstract ideas portrayed by the effigy are concretized in the somatic sphere of the victim. This to such extent that medical science has been found in some instances to be helpless in counteracting the "spell." The voodoo spell is then a suggestive system whereby the abstract may become demonstrably concretized both in the form of experiences and bodily changes. Thought as word and image becomes here experience as feeling and flesh. Voodoo is effective as long as there is a shared belief in the reality of assumed notions. The voodoo doll is the shared symbol of the victim's self.

Symbols are representations of man's notions about Reality. Symbols are products of man's desire to give form to that which forever must remain formless (2). "I am That I am" said God to Moses on Mount Horeb. Which means "I am that which forever Is," or "I am that which really Is." In human consciousness the body tends to be a symbol of the self. Body sensations thus become symbolic thoughts (dreams) about reality of the self. Human thinking is prevalently dedicated to proving the reality of one important basic assumption. Namely, that man exists as a separate and self-sustaining entity in time and space. In other words, human thinking is prevalently preoccupied with self-confirmation. This type of thinking is always circular and it circles around its own hypothetical center.

Bodily sensations tend to reveal in symbolic fashion self-confirmatory desires. The body becomes the symbolic manifestation of thought mistaking itself for reality. In other words, the body reveals man's inclination to view reality from that center which calls itself the self. 
The question may be asked: What is that center around which the self-centered man is centered: Where is this center located? What does it consist of? And how does it come into being?

The self is a conceptual center of being, built up from accumulated assumptions about the nature of reality as mediated by the sensory apparatus and discursive thought. "Nihil est in intellectu quod primum non fuerit in sensu." The intellect knows only that which has come through the senses. The self is then built up from what appears to be and what should be. Moreover, what "should be" insists on ignoring what really is.

Concepts are statements about reality. They have no reality of their own and their location is in that unknown place which is called memory and mind. Thus the self, or the "I am" can neither be localized nor does it have actual reality of its own. Yet ordinary man spends most of his life in an unceasing effort to confirm this abstraction as a concrete reality. The need to confirm the reality of the self is in itself evidence of a lurking doubt existing in the awareness of man.

It is then this disquieting, lurking doubt which underlies the ubiquitous human inclination toward self-assertiveness. When self-assertive man becomes aware of the suffering which he brings upon himself and others, he attempts to behave in self-restraining or self-effacing ways. However, self-restraint is but the assertion of the self against itself. Therefore it only leads to further suffering. For both, self-assertiveness and self-restraint are both ignoring what really is by being preoccupied with what "should be." Ignorance is that mental activity which ignores what really is.

In contemplating human existence and social life as an endless scramble and struggle with the problem of self-confirmation, one is faced with a fountain of dispair, conflict and suffering.

The significance of childhood experiences and cultural trends lies to a great extent in the fact that they provide people with particular patterns of self-confirmatory strivings.

The tragic element of the human condition is rooted in that cognitive defficiency which underlies the desire of man to confirm his self as reality. Since the self is that which "should be," it is not possible to confirm it constructively. For only the confirming of what really is can be constructive. The effort at confirming what "should be" is therefore destructive of reality. Consequently it is pathogenic. Disease is that shadow which the "I am" casts upon Existence. For "I am" to be reality the world must be destroyed. The acute psychotic experience of world destruction is the birth of the delusion concerning an autonomous, exclusive "I am."

One young man teetering on the brink of a psychotic break, was so involved in selfconfirmatory preoccupations in the form of grandiose boasting that when he tried not to boast, he became plagued with painful erections. When the errections were understood as vicarious boasting on a sexual plane, he lost his erections but began to feel cramps in his lower extremities. When these were understood as body language saying "I am," these also left him. At this point, he began to feel a need to tighten his shoe laces repeatedly to keep himself "together," that is, to feel himself as a self.

Suffering is the consequence of that cognitive deficiency in man which gives rise to self-confirmatory desires. Self-confirmatory strivings keep man in a state of ignorance 
by inducing him to ignore that which really is. Physical suffering is the body's way of being in the process of confirming itself. The "body-mind" speaks directly prior to verbal language. Language is one step removed from the event of self-confirmation taking place in the organism.

As long as artistic expression is of self-confirmatory nature, it is not truly creative and has little integrative value. True art is expressive of Reality. Which does not mean that it is of necessity realistic in the conventional sense of the word. True art illumines the hitherto unseen. It broadens man's consciousness and cognition. It is therefore integrative both for the artist and the observer. Creativity has its meaning in illuminating man's relationship to his ontological Ground. The creative artist helps man to see and worship.

The progressive dissolution of the object in modern painting can be understood as the present-day expression of the perennial search for intuitive cognition of Reality. Modern art is thus a record of the artist's cognition of Reality. Art is at once a medium of cognition, documentation and communication of the artist's quest for Ultimate Reality. As man is, so is his cognition. As a true artist creates, so is he. The true artist and his creation are one. By searching for Reality the artist is ultimately seeking his own place in it. As a man's cognition is, so is he. (3)

It is interesting to note the essentially opposing directions which characterize modern art and mental disease. Both, modern art and mental disease, are manifestations of man's struggle for Reality. Mental disease desires to clutch at the object world even at the price of concretization of the abstract, that is, objectification of thought. Whereas modern art moves in the direction of abstraction and dissolution of the concrete object beyond thought into pure experience. The mentally sick desires to lean on sensory perception as a foundation for contact with Reality. The modern artist seeks to go beyond the senses toward the intuitive transcending-loving mode of cognition of Reality.

We could say that the mentally sick are aware of the non-objective world and are threatened by it, whereas the healthy artist enters it in free choice and is able to return from it unscathed, even enriched in his being. The mentally sick lives in dread of No-thingness and strives to escape from it; the healthy artist seeks to embrace it and know it reverently.

When man becomes aware of the suffering inherent in idolatry of the self, or the other, or of what "seems to be" and what "should be," he discovers that "self-realization" is an altogether misleading idea, both in art as well as in psychiatry. Health is contingent not on self-realization but on realization of Reality.

Selfishness, indifference and inconsiderateness are revealed as consequences of insufficient cognition prevailing in common man. Self-centered man calculates, plots and schemes his own self-confirmation. In the process he unfailingly hurts and harms himself and others. It seems that most human suffering reveals the presence of self-centeredness and calculative thinking.

If however, the self is thus revealed as unreal and empty, the question arises as to what is really Real? If all that is unreal is essentially sensory and conceptual, then true Reality must be that which is beyond the sensory and the conceptual. Which means that there must be a mode of consciousness which transcends the sensory and the conceptual. It must be then supra-sensory and transcending. Man awakens to its realization in proportion to 
his understanding of the limitations of the sensory and conceptual spheres of preoccupation. At this point self-consciousness yields to transcending consciousness. (4)

Enlightened man transcends his self in "seeing the truth of what is." In this process of losing himself he finds that which is Real. He heals, that is, he becomes whole (holy) in his "at-one-ment" with Reality. The seer becomes the seeing and the seeing becomes the seen. Love is thus re-cognized (rediscovered) to be a mode of cognition. Love is found to be that Intelligence which forever reveals itself as Understanding. (5)

In the experience of understanding the true nature of Reality is revealed. In it there is neither "self" nor "other"; there is only the all-transcending timeless process manifesting itself in that "field of phenomena" which man is the medium of. (L'homme clairière de l'Existence.) (6)

Self-centered consciousness does not discern the Ground of Being. Interpersonal consciousness is focused on the interaction of the self and the other. It equally fails to see that background without which foreground could not appear. The interpersonal focus ignores the truth of what really is because it is concerned with the relationship of the self to the other. It does not realize that the self is the same as the other, since the other is but an other self. In the realm of understanding there is neither "self" nor "other," there is only that which really is. Love is self-less. It is that background of harmony which is obscured but also revealed by the foreground of the discordant self.

\section{BIBLIOGRAPHY}

1. Legge, J. The texts of Taoism. New York: Julian Press, 1959.

2. Hora, T. Reality and dread. (To be published.)

3. Haas, W.S. The destiny of the mind. Enst and West. New York: Macmillan, 1956.

4. Hora, T. Transcendence and healing. J. exist.
Psychiat., 1961, Spring.

5. Hora, T. Existential psychiatry and group psychotherapy. Amer. J. Psychoanal., 1961, 21, No. 1.

6. Heidegger, M. Sein und Zeit. Tübingen: Max Niemeyer, 1953.

MS. received I 8, 62 . 